\title{
Mortificatie en vivificatie in de Heidelbergse Catechismus
}

\begin{abstract}
Author:
Abraham van de Beek ${ }^{1,2}$

Affiliations:

${ }^{1}$ Faculty of Theology, VU

University, the Netherlands

${ }^{2}$ Faculty of Theology,

University of Stellenbosch,

South Africa

Correspondence to:

Abraham van de Beek

Email:

beekavd@xs4all.nl

Postal address:

PO Box 12485, Stellenbosch

7613 , South Africa

Dates:

Received: 08 July 2015

Accepted: 22 Sept. 2015

Published: 12 Nov. 2015

How to cite this article:

Van de Beek, A., 2015,

'Mortificatie en vivificatie

in de Heidelbergse

Catechismus', In die Skriflig

49(1), Art. \#2008, 8 pages.

http://dx.doi.org/10.4102/

ids.v49i1.2008

\section{Copyright:}

(c) 2015. The Authors.

Licensee: AOSIS

OpenJournals. This work is

licensed under the Creative

Commons Attribution

License.
\end{abstract}

Read online:

Scan this QR

code with your

smart phone or mobile device

to read online.
Dit artikel richt zich op kritiek die geleverd is op het gedeelte over de dankbaarheid in de Heidelbergse Catechismus. Enerzijds is er kritiek dat de catechismus te negatief is over de vernieuwing van het leven van christenen. Anderzijds wordt gesteld dat de nadruk op dankbaarheid leidt tot een nieuwe vorm van knechtschap. Daartegenover wordt in dit artikel betoogd dat de negatieve benadering van de geboden in de catechismus haar wortels heeft in de decaloog en in de wijze waarop zowel het Oude als het Nieuwe Testament spreekt over het leven naar Gods wil. Het nieuwe leven is een vrije gave van God en daarom nooit een verplichting maar vrijheid. Deze wordt alleen bedreigd door de menselijke neiging om het eigen leven zeker te stellen. Door deze neiging wordt het vertrouwen in Gods gunst ontkend. Aangezien het Oude en het Nieuwe Testament beide deze menselijke neiging bestrijden is de paraenese dikwijls negatief geformuleerd en de Heidelbergse Catechismus volgt hen daarin.

This article deals with critiques to the section on 'Gratitude' in the Heidelberg Catechism. On the one hand the catechism is said to be too negative about Christian renewal. On the other hand, its stress on gratitude appears to evoke a new servitude. In contrast to these criticisms, this article argues that the negative approach of the Catechism to the commandments has its roots in the Decalogue and in the calling to live according to God's will as found in both the Old and the New Testament. The new life is God's free gift and therefore never an obligation, but freedom, which is only endangered by the human inclination to secure life. By doing so, trust in God's gift of freedom is negated. Since both the Old and the New Testament oppose this human inclination, the paraenesis is often formulated negatively and the Heidelberg Catechism follows this approach.

\section{Inleiding}

Rond het jubileum van de vierhonderdvijftigste verjaardag van de Heidelbergse Catechismus zijn er veel publicaties verschenen over dit belijdenisgeschrift. Alom werden de kwaliteiten van dit document geroemd en werd de grote invloed die het heeft gehad in de gereformeerde traditie beschreven. Het is de toon die gezet wordt in de eerste vraag en in het antwoord daarop die de Heidelbergse Catechismus (vanaf nu: 'de catechismus') tot een troostboek heeft gemaakt en de uitwerking daarvan heeft generaties gelovigen gevormd.

Dit wil niet zeggen dat er geen kritiek is. Ook die is naar buiten gekomen tijdens het jubileumjaar, maar heeft een lange geschiedenis. Vanaf het begin waren er bezwaren tegen de catechismus (Lekkerkerker 1964:131-139). Deze kritiek richtte zich allereerst op de stelling dat de mens geneigd is tot alle kwaad (antw. 5; zie Lekkerkerker 1964:131-134). Verder is er kritiek op de anselmiaanse verzoeningsleer die de catechismus voorstaat: God vergeeft niet zomaar, maar er moet betaald worden voor zijn geschonden eer (zie Lekkerkerker 1964:136). Daarachter lijkt een godsbeeld te zitten van een wraakzuchtige God die uit is op vergelding in plaats van vergeving. Deze kritiek is weersproken door Abraham van de Beek die aantoont dat de idee van eer en recht contextueel moet worden verstaan en juist willekeur en wreedheid bestrijdt (Van de Beek 2014). Juist de nadruk op de eer van God moet worden verstaan als een afweer van God als tiran. Zijn eer heeft met zijn recht en zijn trouw te doen.

Er zijn echter niet alleen kritische opmerkingen gemaakt bij de stukken van de ellende en de verlossing, maar ook bij het stuk van de dankbaarheid. Deze kritiek richt zich enerzijds op het concept 'dankbaarheid' als zodanig (Wannenwetsch 1997:48-52) en anderzijds op een onevenwichtige behandeling van de mortificatio en de vivificatio in het derde deel van de catechismus (Van Vlastuin 2015). Dit artikel richt zich op deze kritiek op het stuk van de dankbaarheid. We zetten in met de verhouding van afsterving en levendmaking en komen vervolgens tot de vraag welke betekenis de dankbaarheid heeft in de catechismus. 


\section{Onevenwichtig}

Van Vlastuin (2015) betoogt dat de uitwerking van het leven als christen in het derde deel van de catechismus geen recht doet aan de theologische structuur die de catechismus zelf biedt. De catechismus verbindt voortdurend de drie stukken van het geloof met elkaar. Het is niet zo dat er eerst ellende is, dan verlossing en, nadat die stations gepasseerd zijn, het leven der dankbaarheid begint. Het nieuwe leven is vanaf de eerste vraag aanwezig en de ellende en verlossing blijven doorklinken tot in het laatste deel. Dat laat zich aflezen aan het gebruik van de wet. Deze is enerzijds een bron van kennis van onze ellende, omdat we de geboden van God niet gehoorzamen. De wet doet zonde kennen; dat is de usus elenchticus van de wet, haar ontmaskerende functie. Naast de theologisch minder uitgewerkte betekenis van de wet voor het civiele leven schenkt de catechismus vooral aandacht aan de derde functie van de wet: als regel voor het nieuwe leven, de usus normativus. Deze derde functie wordt vooral in de gereformeerde theologie breed uitgewerkt en kan als een karakteristiek van deze traditie gelden. De catechismus past daar geheel in met haar brede uiteenzettingen over de dankbaarheid en haar uitvoerige behandeling van de geboden als regel voor het nieuwe leven. Dat leven betekent niet dat de verloste mens de verzoening achter zich kan laten omdat die afgerond is, maar veeleer dat in een voortdurende wisselwerking zonde, genade en vernieuwing met elkaar verweven zijn. De toon daarvoor wordt gezet door vraag en antwoord 88-90, met als kern de afsterving van de oude mens, 'een innig berouw dat wij God met onze zonden vertoornd hebben, en die hoe langer hoe meer haten en ontvluchten', en de opstanding van de nieuwe mens, 'een hartelijke vreugde in God door Christus en een ernstig liefdevol verlangen om naar de wil van God alle goede werken te verrichten' (vertaling Zwanepol \& Van Campenhout 2009:99). Deze vraag en antwoord kunnen gelden als expressie van de karakteristiek gereformeerde benadering van het leven van de gelovige. Daarin is er een omgang met God en zijn geboden die alle aspecten van het geloof dagelijks doet oplichten. De verschillende aspecten van de wet zijn daarvoor representatief: er is de usus elenchticus waardoor we dagelijks worden ontmaskerd 'dat wij ons met zulk een ijver om God te dienen niet begeven als we schuldig zijn' (Formulier voor het Heilig Avondmaal, Dienstboek in ontwerp, 85), waardoor we dagelijks alleen maar kunnen leven door de genade van Christus die in onze plaats de wet heeft vervuld en de straf gedragen. Er is echter ook dagelijks de vreugde van het nieuwe leven, waarin we ons verheugen om het goede te doen in het houden van Gods goede gebod dat het leven vrij maakt. Dagelijks sterven we aan ons oude leven en dagelijks worden we levend in de vreugde van God om zijn geboden te doen. Dit is geen pas op de plaats maar een groei in het geloof: steeds meer de zonde laten door eraan af te sterven en steeds meer vreugde vinden in het leven volgens het gebod van God.

Tot zover blijft de catechismus geheel in lijn met de gereformeerde traditie zoals Calvijn daarvoor de toon gezet heeft. Dan volgt echter de uitwerking daarvan in het gedeelte in vraag en antwoord 94-113 en daar verliest volgens Van Vlastuin de catechismus deze toonhoogte. Dat wordt zichtbaar als men in de catechismus de conclusie leest na de behandeling van de geboden. Dan luidt de vraag: 'Maar kunnen de degenen die tot God bekeerd zijn, deze geboden volkomen houden?' Het antwoord is ontnuchterend: 'Nee, ook de allerheiligsten hebben, zolang zij in dit leven zijn slechts een klein begin van deze gehoorzaamheid' (vr. en antw. 114). Als men na deze laatste noot van het lied dat de catechismus heeft gezongen over de wet op het toetsenbord nog eens de beginnoot aanslaat, dan blijkt hoe ver de catechismus in toonhoogte gezakt is. 'The real change that is promised in the theological framework seems to have evaporated after the treatment of the law' (Van Vlastuin 2015:175). Er wordt niet meer gesproken over de hartelijke vreugde in het doen van de geboden, maar de mislukking in het onderhouden daarvan is beslissend. Veenhof heeft al eerder gewezen op de zuinige manier waarop de catechismus spreekt over de vernieuwing van de gelovige. 'De gedachte van de Heidelbergse Catechismus antwoord 114, dat ook de allerheiligsten in dit leven slechts een klein beginsel van de gehoorzaamheid hebben, blijft onder het niveau van Paulus' (Veenhof 2005:218).

De negatieve toon van antwoord 114 werd al in de zestiende eeuw bestreden door Coornhert (Lekkerkerker 1964:132). Volgens Van Vlastuin past deze niet bij het paradigma van de catechismus:

If this longing for renewal is compared with the interpretative framework for the treatment of the law, it appears that the conclusion of this treatment differs qualitatively from the proposed framework. While a joy in God and a delight in living for God is spoken about in the proposed framework for the treatment of the law, in the conclusion this aspect has disappeared. What remains is the duty of renewal and the prayer for the Holy Spirit to assist us in fulfilling this duty. The walking of the believer in the new life of Christ by the power of the Spirit is missing from this evaluation. (Van Vlastuin 2015:175)

Deze conclusie over het doen van de wet komt in de catechismus niet uit het niets op. Reeds in de behandeling van de afzonderlijke geboden blijkt dat de hoge toon van de inleiding in antwoord 89 niet behouden blijft. De vragen zijn in de regel nog positief geformuleerd: 'Wat gebiedt God?' maar de antwoorden zetten merendeels negatief in. 'While the catechism asks for the positive meaning of the commandment, the answer begins with the things that are forbidden' (Van Vlastuin 2015:177). Het gaat niet meer om het goede gebod en een positieve inzet voor een leven in de blijdschap, maar om een afweer van het kwade. Het gaat niet meer om een gebod maar om een verbod, niet meer om wat men mag en kan doen, maar om wat men niet mag doen. Het is deze benadering die overheersend is bij de behandeling van de geboden:

If this emphasis on the duties of the believer is compared to the general framework of the treatment of law, it appears that delighting in the law of God and walking in the fulfilled law is absent. (Van Vlastuin 2015:178)

Alleen bij het vierde en vijfde gebod wijkt de catechismus daarvan af. Door de negatieve benadering van de geboden 
in de catechismus wordt de mens niet in aanraking gebracht met het leven in de liefde maar geconfronteerd met zijn zonden. Zo wordt de usus elenchticus het dominante paradigma voor de behandeling van de geboden in het deel der dankbaarheid en is men weer terug bij de ellende:

The first part of the answer is not related to vivification as the positive side of conversion, but to the negative side of conversion in mortification, namely the necessity of understanding our sinful nature at a more profound level. (Van Vlastuin 2015:175)

Mensen zijn niet in staat de geboden te houden en ze kunnen alleen bidden om vergeving en bewaring tegen het kwade. Het is geheel in de lijn van dit paradigma dat het gebed wordt gezien als het voornaamste stuk van de dankbaarheid (Van Vlastuin 2015:176). Een christen is allereerst een smekeling en niet een mens die de zonde afweert en met vreugde het goede doet in een dienst van de liefde.

\section{Analyse}

De analyse van Van Vlastuin dat bij de behandeling van de geboden in de catechismus het verbod dominant is, is terecht. Niet alleen wordt bij de meeste geboden ingezet met wat God verbiedt, maar ook is vergeleken met het verbod de behandeling van de positieve aspecten korter en gewoonlijk als een soort aanhangsel bij het eigenlijke verbod gevoegd in een afzonderlijke vraag. En juist bij het zevende gebod, dat over seksualiteit gaat, wordt de liefde op geen enkele wijze positief geformuleerd. Bij het vierde gebod, over de sabbat, dat zou kunnen gaan over de rust en vrede die God schenkt, loopt het antwoord uit op het afwijzen van de zonden: 'dat ik alle dagen van mijn leven afstand van mijn boze werken neem'.

Zelfs bij deze benadering geldt dat men dit alles niet volkomen kan houden. Christenen zijn, ook als bekeerde mensen, niet alleen niet in staat om positieve daden van gerechtigheid en liefde te doen, maar zij zijn ook niet in staat om de zonde buiten de deur te houden. Ze blijven haten, seksuele misstappen begaan, stelen en liegen. Ze blijven afgoden maken en misbruiken de Naam.

Gedachten over bouwen aan het koninkrijk en discipelschap in de dienst van Christus lijken hier mijlenver vandaan te liggen. Het is als het ware een andere wereld. Een hedendaagse christelijke ethiek heeft een volstrekt ander karakter dan het leven der dankbaarheid zoals de catechismus dat schetst. Er wordt niet gesproken over het perspectief van het koninkrijk van God waarin wij geroepen zijn en opgenomen om de gerechtigheid te bevorderen. Het koninkrijk van God komt in de dankbaarheid alleen ter sprake in de vorm van een gebed (vr. en antw. 123). Hopelijk doet God wat mensen niet doen en kennelijk ook niet kunnen en willen doen. Men kan bij een analyse van de catechismus en een vergelijking met hedendaagse vertogen over christelijke ethiek slechts constateren dat Van Vlastuin een understatement maakt als hij de vinger legt bij de negatieve benadering van de catechismus.

$\mathrm{Nu}$ is niet die hedendaagse christelijke ethiek de norm voor hem. Veeleer komt zijn kritiek voort uit de bijbelse theologie van het Nieuwe Testament. Door het nieuwtestamentische onderzoek zijn we ons bewust geworden van het eschatologische karakter van het bestaan als christen (Van Vlastuin 2015:169, 179 e.v.). We zijn nieuwe schepping en dat mag gezien en geleefd worden. Het is niet een optimistisch humanisme dat Van Vlastuin drijft, maar de Schrift noopt hem tot herbezinning op de inhoud van de catechismus. Daarom heeft hij ook geen kritiek op de eerste twee stukken van de catechismus, zoals theologen die veel meer door het humanistische gedachtegoed en een positieve idee over de mens zijn beïnvloed. In zijn kritiek op het derde deel van de catechismus beweegt hij zich juist in de lijn van de gereformeerde traditie: de belijdenisgeschriften zijn niet canoniek. Ze blijven mensenwerk en staan open voor kritiek vanuit de Schrift. Daarom wordt het tijd om na te gaan waarom de catechismus voor deze benadering kiest en of deze inderdaad wel strookt met de Schrift.

\section{De decaloog}

Van Vlastuin brengt het accent op de usus elenchticus van de wet in het derde deel van de catechismus in verband met het lutheranisme (Van Vlastuin 2015:167 e.v., 170 e.v., 175). De opvatting over het normatieve gebruik van de wet is immers een van de springende verschilpunten tussen lutheranen en gereformeerden. In wezen is de catechismus niet gereformeerd in zijn behandeling van de geboden.

Het is de vraag of deze relatie met de lutheranen zo gelegd kan worden. De stellingen tussen gereformeerden en lutheranen zijn pas echt betrokken in de latere zestiende eeuw. Als men de catechismussen van Luther zelf naast de Heidelberger legt dan spreekt Luther zeer positief over het doen van de geboden:

So haben wir nun die zehn Gebote, ein Ausbund göttlicher Lehre, was wir tun sollen, dass unser ganzes Leben Gott gefalle, und den rechten Born und die Röhre, aus und in welchem quellen und gehen müssen alles, was gute Werk sein solle. (Luther 1938:369)

Aus diesem siehet man ..., wie hoch die zehn Gebote zu heben und preisen sind über alle Stände, Gebote und Werke, so man sonst lehret und treibt. Denn hier können wir trotzen und sagen: lasst auftreten alle Weisen und Heiligen, ob sie könnten ein Werk hervorbringen, als diese Gebote, so Gott mit solchem Ernst fordert, und befiehlt bei seinen höchsten Zorn und Strafe, dazu soherrliche Verheissung dazusetzet, dass er uns mit allen Gütern und Segen überschütten will. Darum soll man sie immer vor allen andern lehren, teuer und wert halten, als den höchsten Schatz, von Gott gegeben. (Luther 1938:374)

Er is niets dat ook maar een zweem van antinominianisme zou kunnen aanduiden. Er is geen verschil tussen deze catechismussen en die van Genève op dit punt (zie ook Verboom 1996:271).

Men moet dus het minimaliseren van een vreugdevol nieuw leven voor christenen en de nadruk op het verbieden in de Heidelbergse Catechismus niet bij Luther zoeken. Veeleer is deze gelegen in de decaloog, die in het stuk over de geboden 
immers de leidraad is. In de decaloog zelf overheerst het verbod. Acht van de tien geboden zetten in met ' $U$ mag niet ...'. Er is zelfs geen nuancering met een verwijzing naar een positieve betekenis zoals de Heidelbergse Catechismus die (net als Luther) wel heeft. De positieve aspecten van de geboden mogen daarin mager uitgewerkt zijn, maar ze zijn er tenminste. Bij het achtste gebod wordt niet alleen het stelen verboden (antw. 110), maar ook gezegd dat we het belang van de ander moeten bevorderen en de armen helpen (antw. 111). Daarin gaat de catechismus verder en spreekt deze positiever dan de decaloog die het simpel bij: 'Je mag niet stelen' houdt.

De catechismus volgt dus de decaloog in haar inzet bij respectievelijk geboden en verboden en doet dat ruimhartig zodat het positieve uit de decaloog gemaximaliseerd wordt door het aanbrengen van positieve accenten bij de verboden (Verboom 1996:278):

Abgesehen davon, dass die genaue Interpretation des Gesetzes im Heidelberger Katechismus im Zusammenhang mit dem dritten Gebrauch des Gesetzes, im Rahmen der Ausführungen über die Dankbarkeit erfolgt, kommt diese Tendenz besonders deutlich darin zum Ausdruck, das viertens das Gesetz im Heidelberger Katechismus auch in ungemein positiver Form interpretiert wird. Wenn ... gerade auch in der Bibel das Verbot nicht fehlt ... und selbst im sog. Hohenlied der Liebe (1 Kor. 13) die Liebe fast ausschliesslich negativ umschrieben wird, so versteht der Heidelberger Katechismus die Gebote ziemlich konzequent eben als Ge-bote. (Büsser 1963:166; zie ook Latzel 2004:88)

Ook de beide geboden die eenduidig als een gebod geformuleerd staan, hebben in de decaloog een negatieve spits. Het gebod om de sabbat te houden wordt ingevuld vanuit het verbod om werk te doen op de sabbat (Ex 20:10; Deut 5:14). Dat verbod wordt zo wijd mogelijk geformuleerd. Het strekt zich uit over alle mensen, tot de vreemdelingen toe. Men kan dit verbod zien als een radicalisering van de andere verboden. De andere verboden verbieden om iets verkeerds te doen; het sabbatsgebod verbiedt om überhaupt iets te doen. Als de sabbat de heilige dag van de week is, dan geldt dit als het hoogste goed. Om praktische redenen moet men wel zes dagen werken, maar het ideaal is een leven zonder werk. De catechismus strekt het sabbatsgebod inderdaad uit over alle dagen. Deze verbiedt echter niet om al die dagen enig werk te doen, maar zegt dat het gebod ons aanzegt alle dagen afstand te nemen van onze boze werken (antw. 103). De catechismus is hier dus positiever over menselijke activiteit dan de decaloog. Hij geeft al helemaal geen aanleiding tot een puriteinse interpretatie van de zondag als sabbat waarin enig werk verboden wordt. Veeleer komt hier juist het positieve naar voren: dat we een dag mogen hebben om de eredienst te hebben en de oproep aan de overheid om kerken en scholen te stichten. Men kan dit zien als een oproep om te bouwen aan het koninkrijk van God.

Eenzelfde verbrede interpretatie kan men ook vinden bij het vijfde gebod, over het eren van vader en moeder. Gewoonlijk wordt dit gebod opgevat als het eerste van de tweede tafel: over de relatie tot de naaste. Zo vult ook de catechismus dit in: kinderen moeten hun ouders gehoorzamen en die relatie staat symbool voor elke gezagsrelatie. Er is echter reden om dit gebod te betrekken op de relatie tot God. De vader en de moeder staan in het Oude Testament voor de lijn van de traditie. Het gaat niet zozeer om gezinsverhoudingen maar om traditieverhoudingen. De ouders vertegenwoordigen het voorgeslacht, de lijn van Abraham, Isaäk en Jakob en het verbond dat met hen is gesloten. $\mathrm{Zij}$ staan voor het onderwijs in de traditie en de Torah die daarbij behoort:

Hij stelde een richtlijn vast voor Jakob en kondigde in Israël een wet af. Onze voorouders gaf Hij de opdracht die aan hun kinderen te leren. Zo zou het volgende geslacht ervan weten, en zij die nog geboren moesten worden, zouden het weer aan hun kinderen vertellen. Dan zouden zij op God vertrouwen, Gods grote daden niet vergeten en zich richten naar zijn geboden. (Ps 78:5-7; vgl. Spr 1:8; 6:20; 23:22-25)

Als de Israëlieten zich daaraan houden, zullen ze lang leven in het beloofde land (Ex 20:12; Deut 5:16).

Het gebod gaat dus om het bewaren van de traditie van de voorouders. Het is dus evenzeer een verbod als het sabbatsgebod: men mag geen eigen initiatief nemen, want elk eigen initiatief beweegt zich buiten de lijnen van de traditie die ons leven reguleert (Deut 4:2; 13; 30:10-20; 31:16 e.v.; 32:6 e.v.). Zoals het sabbatsgebod het doen van werk tot een noodzakelijk kwaad maakt, zo verbiedt het gebod tot het eren van vader en moeder het eigen initiatief.

Als de catechismus het traditiegebod interpreteert naar menselijke familie- en gezagsrelaties dan wordt daarmee de weg voorbereid voor de latere gereformeerde traditie. Het ideaal is dat kinderen en onderdanen een plezier voor hun ouders en bestuurders zijn door hun bijdrage aan gezin en maatschappij: mensen die iets van hun leven maken als zorgzame kinderen en goede burgers.

In de decaloog overheerst dus het verbod. Daarin staan de Tien Geboden niet geïsoleerd in het Oude Testament. In heel de Torah overheerst het verbod. Telkens weer wordt aan de Israëlieten voorgehouden wat ze niet mogen doen. Het meest sprekend is dat misschien wel bij seksuele en huwelijkswetgeving. Er wordt breed uitgemeten wat er allemaal niet mag en de vervloekingen zijn niet van de lucht (zie bijv. Lev 18:6-20; 20:10-21; Deut 22:22-30), maar er wordt nergens uitgelegd wat een positieve liefdesrelatie tussen mensen is en hoe je daarin met elkaar omgaat. Er wordt wel verboden 'de schaamte' van allerlei anderen te ontbloten, maar niet aangewezen hoe je als geliefden met elkaar omgaat om op vreugdevolle wijze elkaar te beminnen zonder schaamte. Dat blijft bewaard tot de randen van de canon in het Hooglied dat dan ook nog allegorisch moet worden uitgelegd. Op dit punt volgt de catechismus strikt het Oude Testament door bij de behandeling van het zevende gebod alleen het negatieve te noemen (Den Hertog 2012:111).

De catechismus laat zich dus in zijn interpretatie leiden door de decaloog en de context van het Oude Testament waarin 
deze is ingebed, om vervolgens daaraan een interpretatie te geven waarin positieve elementen die aan het gebod kunnen worden verbonden versterkt worden.

\section{Het Nieuwe Testament}

$\mathrm{Nu}$ is de decaloog een deel van het Oude Testament. Men kan de vraag stellen of het omgaan met de wil van God in het Nieuwe Testament niet een ander karakter heeft. Spelen daar woorden als 'liefde', 'vreugde', 'vrede' niet een veel groter rol om het leven van de gelovigen richting te geven? Inderdaad zijn er teksten die het christelijke leven aanduiden als een leven in de vreugde van het nieuwe leven (Rom 15:13), vervuld van liefde en zegen (Rom 12:9-21).

Als we echter letten op de specifieke teksten van de apostolische paraenese, dan blijkt ook daar het negatieve te overheersen. Steeds weer vermanen de apostelen het kwade af te leggen (Rom 13:12; Ef 4:22, 25; Heb 12:1; Jac 1:21; 1 Pet 2:1). Voortdurend worden christenen opgeroepen om het oude leven dat zij als heidenen leidden achter zich te laten (Rom 13:12-14; Gal 5:16-21; Ef 4:17-32; 5:3-13; Kol 3:5-9) en uit de voorbeelden die genoemd worden blijkt hoe moeilijk dit voor hen is (Gal 5:1-15; Fil 4:2).

Gewoonlijk, pas nadat gesproken is over de aflegging van de oude mens met zijn praktijken, komen de vermaningsteksten tot het positieve en meestal is dat veel korter dan het negatieve. Het Nieuwe Testament is dus niet zoveel anders dan het Oude Testament. Zelfs teksten over de eigen christelijke levenshouding in de liefde vinden hun wortels in het Oude Testament, met als kern de samenvatting van de Torah door Jezus: 'Heb de Heer, uw God, lief met heel uw hart en met heel uw ziel en met geheel uw verstand ... Heb uw naaste lief als u zelf' (Matt 22:37, 39). De invulling daarvan is zowel in het Oude als in het Nieuwe Testament echter vooral dat men kwade praktijken nalaat. Misschien is dat in het Oude Testament sterker, maar dat zijn accentverschillen en geen fundamenteel ander paradigma.

Het is belangrijk te letten op de aard van de positieve omschrijvingen van het christelijke leven. Dan gaat het om begrippen als 'zachtmoedigheid', 'geduld', 'verdragen' en dergelijke (Rom 12:12; 1 Kor 4:12; Gal 5:22; 6:2; Ef 4:2; Kol 3:12; Tit 3:2; Jac 3:13; 4:6; 5:10; 1 Pet 2:19; 5:5). Het zijn vooral passieve eigenschappen. Het zijn geen dingen die men doet maar die weergeven wat men ondergaat. Het zijn geen activiteiten, maar passiviteiten. Ze liggen in de lijn van het sabbatsgebod: de vervulling van de wet is het afzien van werken. Zo is ook de toon van de bergrede.

Met deze levenshouding bouwt men geen sterke samenleving op en geen koninkrijk van God, zou men denken. Het is dan ook niet verwonderlijk dat de meest indringende momenten in het Nieuwe Testament die gaan over vernieuwing van het leven van christenen de vorm van een gebed hebben, zoals in Efeziërs 3:14-17. Juist in deze teksten over het gebed overheerst het positieve, het goede en de liefde.
Men moet dus concluderen dat de uiteenzetting van het christelijke leven in het stuk van de dankbaarheid in de catechismus een weerspiegeling is van zowel het Oude als het Nieuwe Testament. De vreugde van de wet is het afleggen van praktijken die niet deugen, ook als men daarom vervolgd wordt. Het is niet deelnemen aan wat gewoon is onder de heidenen, ook al is men van nature daartoe geneigd. De vreugde der wet is juist daarvan bevrijd te zijn. Daarin stemmen Psalm 119 en Paulus, de profeten en de kerkvaders overeen en in dat koor mengt zich ook de catechismus.

\section{Dankbaar moet je zijn}

Men kan zich afvragen waaruit deze negatieve benadering van de geboden voortkomt. Om dat te begrijpen kan een publicatie van Wannenwetsch ons helpen. Wannenwetsch (1997:48-52) geeft aan dat er ook kritische vragen bij de catechismus gesteld worden vanuit een perspectief dat tegengesteld is aan dat van Van Vlastuin. Van Vlastuin is van mening dat de catechismus meer de nadruk had moeten leggen op het positieve doen van de geboden als vreugde in het onderhouden van de wet. Wannenwetsch vindt dat de catechismus juist te veel nadruk op de verschuldigde dankbaarheid legt. Smit (2013:123) geeft aan dat Wannenwetsch in deze kritiek allerminst alleen staat (Smit noemt naast Wannenwetsch Milbank 1996; 1999; 2001, die zelf weer naar Marion verwijst; Volf 2005; Ward 2000; Webb 1996). Door de vereiste dankbaarheid komt men in de sfeer van de plicht en de verdienste in plaats van te leven in de vrijheid. 'Darum hat derHeidelberger Katechismusdurchaus zu einer problematischen Traditionsbildung beigetragen, indem er die Dankbarkeit als erste Antwort auf die Frage nach dem moralischen Sollen einführt' (Wannenwetsch 1997:51).

Naar het oordeel van deze kritische auteurs impliceert de verplichting tot dankbaarheid die gegeven is met het normatieve karakter van de tertius usus legis als richtlijn voor het nieuwe leven dat we iets moeten terugdoen voor God. Omdat Hij ons gered heeft door Christus moeten wij dankbaar zijn en dat door onze daden bewijzen. Voor wat hoort wat. Het is wel niet het klassieke schema van do ut des waarbij de goden door offers gemanipuleerd worden om ons gunstig gestemd te zijn, maar er is wel een correlatie tussen de gunst van God en onze gaven. Je moet dankbaar zijn en als je dat niet bent, neemt God je dat kwalijk.

Door zo'n benadering wordt het vrije karakter van Gods genade verduisterd: 'Dankbarkeit moralisiert den Dank' (Wannenwetsch 1997:51). Gods relatie tot ons wordtbeïnvloed door onze daden. Niet de verplichting tot dankbaarheid zou moeten volgen op de genade van God, maar de vrijheid van een christenmens. Dat die vrijheid het leven van mensen beïnvloedt moge duidelijk zijn, maar dan gaat het om een spontane verandering omdat het juk van de wet gebroken is. Dat is iets heel anders dan de bewuste, gereflecteerde verplichting tot dankbaarheid - die vervolgens nooit genoeg 
is, want zij kan nooit recht doen aan de grootheid van Gods genade:

'Dankbarkeit' ... verrät eine knechtische Gesinnung. Sie gehört zur 'Sklavenmoral', zum Habitus derer, die sich in der je nach dem gnädig gewärten Gegenwart des Patriarchen üben müssen, weil sie keinen freien Zugang zu ihm haben. (Wannenwetsch 1997:52)

Als we het verplichtende karakter van de dankbaarheid centraal zetten, worden de geboden inderdaad een nieuwe wet der werken en strijdt deze tegen de genade (Rom 4:2). Zo heeft het stuk van de dankbaarheid vaak gefunctioneerd in de gereformeerde traditie. Mensen moesten vooral veel doen om te tonen dat zij ware gelovigen waren. Ze moesten iets doen om te laten zien dat ze genade ontvangen hadden. Juist de liefde van God die in de genade gegeven is werd zo tot een harde verplichting. Men moet zich immers veel meer verplicht voelen om te doen wat een liefdevolle vader wil, dan waneer er alleen een harde eis van een straffende God bestaat. Veel christenen hebben geleden onder het 'nooit genoeg' van alles wat ze deden (Den Hertog 2012:107). Ze voelden zich altijd schuldig. Dit werd niet zelden gestimuleerd door anderen die zelf vonden dat ze wel een trap hoger in het leven van de dankbaarheid stonden - of van mensen die hun eigen frustratie probeerden te overwinnen door anderen op hun gebreken te wijzen. Schuldbesef en geborneerdheid waren het resultaat van de verplichting tot dankbaarheid.

Het is zeer de vraag of dit de bedoeling van de catechismus is (Smit 2013:124). Zondag 32 geeft zeker aanleiding om zo te denken: we moeten goede werken doen om met geheel ons leven God dankbaarheid te bewijzen voor zijn weldaden en door die werken worden we verzekerd van ons geloof. Wie geen goede werken heeft, kan niet worden gered. Daarmee zet het gedeelte over de geboden in. Aan het slot van de behandeling daarvan komt echter de conclusie die in een heel andere richting wijst: niemand is in staat om de geboden volkomen te houden, hooguit is er een klein begin. Dit betekent echter niet dat ieder alsnog verloren gaat, maar dat we des te meer alleen op Christus hopen en bidden om de Heilige Geest om ons te vernieuwen. Daarom loopt het stuk van de dankbaarheid uit op het gebed. De oproep om de geboden te doen brengt de gelovigen dus tot een houding van volstrekte afhankelijkheid van Christus en zijn Geest.

Smit (2013:123-128) heeft de inzet van de catechismus in antwoord op het verwijt van Wannenwetsch helder uiteengezet door de aard van het leven in de dankbaarheid te stellen in het licht van zondag 1:

Die Kategismus se eie bedoeling blyk al glashelder ... uit die bekende Antwoord 1. Die probleem is waarskynlik dat die tradisie meestal halfpad opgehou het by die lees van hierdie antwoord. (Smit 2013:124)

Antwoord 1 eindigt immers met dat Christus ons door zijn Geest 'van harte gewillig en bereid maakt om voortaan Hem toegewijd te leven':

Is dankbaarheid die eis tot menslike reaksie óp die vrye guns, of is dankbaarheid self déél van die werking van die vrye guns?
Is dankbaarheid die gepaste handeling van menslike kant in die lig van die voorafgaande genadige Goddelike handeling - in die gees van dit het Ek alles vir jou gedoen, wat doen jy nou vir My? Of is dankbaarheid die integrale en spontane werking van die Goddelike handeling self? (Smit 2013:124)

In het licht van zondag 1 is het antwoord op deze vraag zonneklaar: ook het leven der dankbaarheid is gave van God en dus 'self deel van die troos' (Smit 2013:124).

In de receptiegeschiedenis van de catechismus kan men deze twee lijnen in de benadering van de dankbaarheid terugvinden. Enerzijds vindt men commentatoren die het accent leggen op de verplichting:

Wien kan [het werk van Christus] vrede geven en vertroosten, tenzy hy ook werkelik des Heeren wet beminne? Daarom toont hy, dat men, om getroost te leven, ter erkentenisse van die verlossinge ook goede werken te betrachten hebbe. (Van der Kemp 1737:630, 634)

Deze nadruk op de plicht is echter niet dominant. Veeleer wijzen uitleggers op de totale samenhang van de catechismus en geven de dankbaarheid een plaats in de vrijheid van de verloste mens (bijv. Busch 1998:226-223; Van Oosterzee 1877:470-485; 503 e.v.; Verboom 1996:246-249; 277-280):

Let wel, die werken gaan hun niet vóor, om de gesloten deur te ontsluiten, dàt is door Christus gedaan; maar zij vólgen met hen, om dáar voor den troon van de levendigheid huns geloofs te getuigen, en het genot der rust na gedane arbeid nog eindeloos te verhoogen. (Van Oosterzee 1877:481)

De verplichting tot dankbaarheid die als een last op de schouders van de gelovigen drukt is eerder het resultaat van invloeden uit het piëtisme en puritanisme dan van theologische reflectie op de Heidelberger.

Van Vlastuin zet in met de positieve opdracht van de geboden die antwoord 90 zo mooi formuleert en waarvan men in de behandeling van de geboden niet veel terugvindt en die in de slotconclusie in vraag en antwoord 114 slechts in het tegendeel verandert. Wannenwetsch legt juist de nadruk op het eisende aspect van de goede werken in zondag 32 en ziet dat als tegengesteld aan de genade. Als we echter de conclusie erbij betrekken dan blijkt dat die eis alleen een verdieping van de genade bewerkt en een biddend leven, in volstrekte afhankelijkheid van God. Het is het losmaken van de inleiding van het deel over de geboden van de conclusie en van het gebed als voornaamste stuk der dankbaarheid die de houding van veel gereformeerden heeft bewerkt die Wannenwetsch terecht bekritiseert. Als we die evenwel goed in het oog houden, ontstaat een ander beeld: dan komt het eschatologische karakter van het geloof dat Van Vlastuin mist in de catechismus juist ten volle naar voren: 'dat wij hoe langer hoe meer naar het beeld van God vernieuwd worden, tot wij na dit leven de volkomenheid bereiken die ons in het vooruitzicht is gesteld' (antw. 115). Leven uit de genade is volstrekte overgave aan en volkomen afhankelijkheid van Gods genade en het groeien van een christen is een groeien in deze levenshouding (Busch 1998:228). Daartoe dienen de 
geboden en deze dienen in het stuk der dankbaarheid tot een verdieping van dat leven van de dankbaarheid in het belangrijkste aspect daarvan: het gebed:

Waarom dan nog goeie werke, vra die Kategismus, as ons 'sonder verdienste', 'alleen uit genade' uit 'ons ellende' verlos is? Omdat Christus ons deur sy Heilige Gees vernuwe, tot sy ewebeeld - dis ons troos. (Smit 2013:127)

\section{Van het kwade vandaan vluchten}

De kritiek van Wannenwetsch is de opening naar het begrijpen van het negatieve karakter van de geboden. Actief het leven inrichten naar Gods geboden leidt tot frustratie of tot eigenroem. Het moeten overheerst de genade. Zowel het Oude en het Nieuwe Testament als de Heidelbergse Catechismus snijden deze weg af.

In het Oude Testament wordt het gavenkarakter van het leven van Israël in het land benadrukt. 'Niet uw eigen rechtvaardigheid of uw zuivere geweten geeft $u$ toegang tot hun land.' Israël krijgt het land 'omdat Hij zich wil houden aan de eed die Hij uw voorouders Abraham, Isaäk en Jakob heeft gezworen', zegt Mozes (Deut 9:5). Het bezit van het land is geen prestatie maar een geschenk. Ook het leven in het land werd daardoor gekenmerkt. In Egypte moesten de mensen van alles organiseren om het land vruchtbaar te houden. Een goed geregeld irrigatiesysteem was nodig en daarom een strakke organisatie onder het gezag van de farao. Voor Israël was het geheel anders. Israël krijgt 'een land met bergen en dalen, dat zijn dorst lest met het water uit de hemel. Het is een land waaraan de Heer, uw God, veel zorg besteedt en waarover Hij waakt, het hele jaar door' (Deut 11:11 e.v.). Israël leeft in de vrijheid van Gods goede gaven. Zo is het alle jaren dat ze leven in het land en zo is het begonnen. 'Ik ben de Heer, uw God, die u uit Egypte, uit de slavernij, heeft bevrijd' (Ex 20:2; Deut 5:6).

Het risico voor Israël is echter dat ze niet vertrouwen op God en zijn goede gaven en daarom initiatieven gaan nemen om zich veilig te stellen. Zo kunnen ze de verleiding niet weerstaan om een koning te wensen - net als alle andere volken (1 Sam 8:5). Ze willen het initiatief van iemand die voor hen uit gaat. Ze willen ook goden die ze kunnen zien en die ze in de hand hebben (Ex 32). Daarmee wordt het genadeen gavenkarakter van het leven als volk van God ontkend en zo uiteindelijk God zelf niet vertrouwd: 'Jou verwerpen ze niet. Ze verwerpen juist mij als hun koning', zegt de Here tegen Samuël (1 Sam 8:7).

Het is tegen dit eigen initiatief om het eigen leven veilig te stellen dat de geboden zich richten. Ga niet doen wat de heidenen doen: goden kiezen die je passen, God aanpassen aan je wensen, over lijken gaan om jezelf te beschermen, stelen om je bezit te vermeerderen. Je moet niet de mentaliteit hebben van de machoman die vrouwen wil versieren en door ontrouw en leugens leeft ten koste van het geluk van anderen. Alles wordt samengevat in het laatste gebod: 'Je zult niet begeren' - en dat is het resultaat van een verkeerd begin: dat je andere goden naast de God stelt die je in vrijheid en overvloed leven doet.
Het goede leven is geschenk van God. Je hoeft er niets voor te doen. De regen heb je niet in de hand. Dat vertrouwen is moeilijk en daarom zijn mensen geneigd net zo te doen als de heidenen: eigen initiatief ten koste van de anderen omdat je God niet vertrouwt.

Jezus zet volgens het Nieuwe Testament deze lijn voort. 'Vraag je dan niet bezorgd af: "Wat zullen wij eten?" of: "Wat zullen wij drinken?" of: "Waarmee zullen wij ons kleden?" dat zijn allemaal dingen die de heidenen najagen' (Matt 6:31 e.v.). De bergrede staat geheel in de lijn van de decaloog. Vecht niet voor je zelf, maar heb je vijanden lief en keer hun de andere wang toe (Matt 5:39). Zo spreken ook de apostelen over het leven in Christus: de ander belangrijker vinden dan jezelf (Fil 2:3). We leven in de volheid van de genade. We hoeven niet een christelijk leven te organiseren. Om in vrijheid te leven heeft Christus ons vrijgemaakt (Gal 5:11). Het risico is alleen dat mensen die vrijheid niet aandurven en toch weer gaan leven als de heidenen. Dat oude leven raken ze moeilijk kwijt. Daarom roepen de apostelen de gelovigen steeds weer op om dat achter zich te laten. Ze moeten niet gaan vechten voor zichzelf, maar geduldig zijn, verdraagzaam en zachtmoedig.

Het leven van het volk van God in het Oude Testament en in het Nieuwe Testament bestaat niet uit prestatie waardoor iets tot stand wordt gebracht, maar in de vrijheid van het genieten van Gods genadegaven en het vertrouwen in zijn zorg. Omdat het natuurlijke bloed kruipt waar het niet gaan kan, wijzen de apostelen voortdurend op dat risico: geef daaraan niet toe, maar richt je helemaal op Gods genade. In Christus hebben we alles ontvangen en in die eschatologische overvloed leven wij, als nieuwe schepping. Het is alleen een voortdurend gevecht om het heidendom met zijn praktijken los te laten. De eschatologische werkelijkheid bestaat niet uit prestatie maar uit leven in de volheid. Het is dus juist het ontbreken van positieve richtlijnen wat het eschatologische karakter van de geboden aangeeft. Bij het leven in het land en als nieuwe schepping in Christus behoort geen prestatie, maar juist de afweer van de drang die deze prestatie draagt en de gevolgen die daaruit voortkomen.

Het is deze lijn die ook de catechismus volgt in het stuk van de dankbaarheid. Er is een leven in de eschatologische werkelijkheid van Christus. Daarin passen de werken van het oude leven niet meer (Busch 1998:227). Zeer beeldend wordt dit weergegeven door van Oosterzee (1877:482):

Gevoelt gij het niet, dat de onreine nergens erger misplaats zou zijn dan in de woningen van licht en leven? ... Wat zou de gierigaard doen in een kring, waar het goud als slijk wordt geacht; wat de dronkaard en onmatige, waar drank en spijs is te niet gedaan; wat de overspeler waar men niet trouwt, of ten huwelijk uitgeeft, omdat allen zijn als Engelen Gods in den hemel? Neen, voorwaar, op duizend vragen aangaande het leven der toekomst moge het antwoord ons onbekend zijn gebleven: wat de hemel niet zal zijn, het is op dit punt niet raadselachtig. Geen vrijstad der ongerechtigheid; geen schuur waar het onkruid een even veilige plaats als de rijpe tarwe zal vinden; geen hof, waarin de boom der verzoeking nog nevens den levensboom staat. (vergelijk 2 Kor 6:14-18) 
Op dat wat het eschatologische leven niet is, richt zich de negatieve benadering van de geboden in de catechismus: dit soort dingen horen niet bij het eschatologische leven in Christus.

\section{Mortificatio als vivificatio}

Het nieuwe leven van een christen is een leven dat ingebed is in Christus, levend uit zijn genade in vrede en vrijheid. 'Daarmee wordt de dankbaarheid getypeerd. Het is geen optelsom van goede werken, maar een innerlijke gezindheid, die zich uit in goede werken' (Verboom 1996:246). De machten van buiten proberen dit leven steeds weer te verstoren, vooral omdat ook christenen het kwaad van nature in zich dragen. Die machten moeten bestreden worden. Het oude leven moet worden afgelegd. Dat is de mortificatio. In die afsterving van de oude mens worden christenen steeds meer alleen aan Christus gebonden. Door de strijd tegen de zonde worden zij steeds meer afhankelijk van Hem en beseffen zij hoe groot zijn genade is. Daardoor groeit hun verlangen om het oude leven kwijt te raken.

De afsterving van de oude mens en de opstanding van de nieuwe mens zijn dus geen twee parallelle processen, het een negatief en het andere positief, maar het is een en hetzelfde proces. Door het verlies van het oude wordt een christen steeds meer afhankelijk van Christus en zijn Geest. Er hoeft dus geen afzonderlijk proces van vivificatio beschreven te worden. Het is slechts het oude leven dat het volkomen christen-zijn in de weg staat: volkomen afhankelijk van Hem te zijn.

Zo wordt duidelijk dat het gebed het voornaamste stuk van de dankbaarheid is: gebed is alleen maar afhankelijkheid; daar is alles genade. In het gedeelte over de geboden overheerst nog de strijd waardoor we naar Christus toegroeien. In het gebed is er geen strijd meer maar overgave. Dat is het nieuwe leven van een christen.

Dit zegt veel over het discipelschap. De term 'discipelschap' is in de hedendaagse kerkelijke theologie een kernbegrip geworden. Daarmee wordt vooral het positieve bedoeld dat christen kunnen doen in de navolging van Jezus. De catechismus heeft een dieper verstaan van de navolging, in lijn met wat Jezus zelf daarover heeft gezegd: ‘Wie achter mij aan wil komen, moet zichzelf verloochenen, zijn kruis op zich nemen en mij volgen' (Matt 16:24; vgl. Matt 10:38; Mark 8:34; Luk 9:23; 14:27). Het kruis is niet alleen lijden; het is ook en vooral sterven aan de zonde. Discipelschap is dat we leren hoe zwaar het kruis is, om zo de genade te ontvangen dat wij leven in Hem. 'Zodra Christus als bron van de bekering uit het gezichtsveld verdwijnt, zijn we weer terug bij af' (Verboom 1996:250; zie ook Busch 1998:246).

\section{Conclusie}

De catechismus is dus niet zuinig met de levendmaking, maar richt zich geheel op het waarachtige leven: totaal afhankelijk van Christus in Wie alle volheid aanwezig is. Door de conclusie na de behandeling van de decaloog en de uitloop op het gebed wordt ook duidelijk gemaakt dat het niet om dankbaarheid als tegenprestatie gaat, maar dat de diepste dank is dat we ons volstrekt van Hem afhankelijk weten, die gezegd heeft: 'Mijn genade is genoeg voor jou' (2 Kor 12:9). Genoeg is genoeg. Daar hoeft geen prestatie meer bij te komen.

\section{Erkenning}

Dank aan Dr J.P. Gavera voor de correctie van het Engels van de Abstract.

\section{Tegenstrijdige belangen}

De auteur verklaart geen financiële of persoonlijke belangen te hebben die hem ongepast kunnen hebben beïnvloed bij het schrijven van dit artikel.

\section{Literatuurverwijzingen}

Busch, E., 1998, Der Freiheit zugetan: Christlicher Glaube heute - im Gespräch mit dem Heidelberger Katechismus, Neukirchener Verlag, Neukirchen-Vluyn.

Büsser, F., 1963, 'Die Bedeutung des Gesetzes', in F. Coenen (eds.), Handbuch zum Heidelberger Katechismus, pp. 159-170, Neukirchener Verlag des Erziehungsvereins, Neukirchen-Vluyn.

Den Hertog, G., 2012, “"Ein geringer Anfang ... mit fester Absicht”: Die zehn Gebote als Regeln', in M. Heimbucher, C. Schneider-Harpprecht \& A. Siller (Hrsg.), Zugänge zum Heidelberger Katechismus: Geschichte - Themen - Unterricht: Ein Handbuch für die Praxis, pp. 106-112, Neukirchener Verlaggesellschaft, Neukirchen-Vluyn.

Dienstboek in ontwerp voor de Nederlandse Hervormde Kerk, 1983, 8e dr., Boekencentrum, 's-Gravenhage.

Latzel, T., 2004, Theologische Grundzüge der Heidelberger Katechismus: Eine fundamentaltheologische Untersuchung seines Ansatzes zur Glaubenskommunikation, diss., Ruprecht-Karls-Universität.

Lekkerkerker, A.F.N., 1964, Gesprekken over de Heidelberger, Zomer \& Keuning, Wageningen.

Luther, M., 1938, 'Der Grosse Katechismus 1529', in H.H. Borcherdt \& G. Merz (Hrsg.) Martin Luther, Ausgewählte Werke 3, 2. Aufl., pp. 309-438, Kaiser, München.

Milbank, J., 1996, 'Can a gift be given? Prolegomena to a future Trinitarian metaphysic', in L.G Jones \& S.E. Fowl (eds.), Rethinking metaphysics, pp. 119-161, Blackwell, London.

Milbank, J., 1999, 'The ethics of self-sacrifice', First Things 91, 33-38.

Milbank, J., 2001, 'The soul of reciprocity', Modern Theology 17, 335-391; 485-507.

Smit, D.J., 2013, Opstelle oor Gereformeerd-wees vandag: Versamelde opstelle 4 (red. L. Hansen), Beyers Naudé Centre Series on Public Theology, Sun Press, Stellenbosch.

Van de Beek, A., 2014, '... but also just: Reflections on the severe God of the Heidelberg Catechism', Acta Theologica Supplementum 20, 115-128.

Van der Kemp, J., 1737, De christen geheel en al het eigendom van Christus in leven en sterven, vertoont in drieënvyftig predikatiën over den Heidelbergschen Katechismus, 10e dr., Losel \& Bosch, Rotterdam; Verschueren, Amsterdam.

Van Oosterzee, J.J., 1877, De Heidelbergsche Catechismus in twee en vijftig leerredenen, $2 \mathrm{e}$ dr., Kemink, Utrecht.

Van Vlastuin, W., 2015, 'The joy of the law: A revisitation of the usus normativus in the Heidelberg Catechism', Journal of Reformed Theology 9, 166-181. http://dx.doi. org/10.1163/15697312-00902016

Veenhof, J., 2005, Vrij gereformeerd: verzamelde artikelen bezorgd door Dirk van Keulen, Kees van der Kooi, Aad van Egmond en Martien Brinkman, Kok, Kampen.

Verboom, W., 1996, De theologie van de Heidelbergse Catechismus: Twaalf thema's: De context en de latere uitwerking, Boekencentrum, Zoetermeer.

Volf, M., 2005, Free of charge: Giving and forgiving in a culture stripped of grace, Zondervan, Grand Rapids.

Wannenwetsch, B., 1997, Gottesdienst als Lebensform - Ethik für Christenbürger, Kohlhammer Verlag, Stuttgart.

Ward, G., 2000, Cities of God, Routledge, London.

Webb, S., 1996, The gifting God: A Trinitarian ethics of excess, Oxford University Press, Oxford.

Zwanepol, K. \& Van Campenhout, C.H. (reds.), 2009, Belijdenisgeschriften van de Protestantse Kerk in Nederland, Protestantse Pers, Heerenveen. 